\title{
CHARACTERIZATION AND POTENTIALITY EVALUATION OF SOILS FOR ADOPTING NATURAL FARMING - A CASE STUDY OF BABURAYANPETTAI, TAMIL NADU, INDIA
}

\author{
CHIKKARAJU S N $\mathbf{1}^{\mathbf{1}}$, RAVISHANKAR $\mathrm{K}^{\mathbf{2}}$, ANGELIN SILVIYA ${ }^{\mathbf{3}}$ \& SIVACHANDRAN K ${ }^{\mathbf{4}}$ \\ ${ }^{1}$ Asst.Professor, Department of Natural Resource Management, Faculty of Agricultural Sciences, \\ SRM University, Katangkullathur, India
}

${ }^{2}$ Tutor, Department of Natural Resource Management, Faculty of Agricultural Sciences, SRM University, Katangkullathur, India

${ }^{3}$ Asst.Professor, Department of Natural Resource Management, Faculty of Agricultural Sciences, SRM University, Katangkullathur, India

${ }^{4}$ Farm Manager, Department of Agronomy, Faculty of Agricultural Sciences,

SRM University, Katangkullathur, India

\begin{abstract}
Soil resource inventory was done by using cadastral map and with the help of satellite imagery tounderstand the origin and potentiality of soil topractice natural farming in future days. Therefore entire area of Baburayanpattai -SRM Agricultural college area is divided in to three different transact based on variation in elevations and surface features of soil. Three soil pedons are excavated in a single transact which falls under nearly level slopingland, soils are studied for understanding the potentiality for crop growth and characterized in to different classes. Soils in the study area is very deep depth and It was found that surface soils have dark greyish brown colour with clayey texture and having the angular blocky structure. The soil pH ranged from 7.65 to 8.38 from surface to subsurface horizon. Available nitrogen is observed lower in the surface and sub-surface horizons. Phosphorous shows lower status from surface to subsurface horizon because it fixed with cacos as orthocalcium phosphate. Potassium is observed medium to high in status due to the presence of smectitic clay minerals abundantly in the soil. Iron, Manganese and copper are showing more than their critical status, this is due to not chelated with other chelating agent in the soil. It was observed that soils are having some of the limitations like drainage and heavy clay content. Therefore to eradicate these limitations natural farming with tree farming is advised to practice instead of inorganic farming.

KEYWORDS: Natural farming, Characterization, Potentiality
\end{abstract}

Received: Oct 16, 2020; Accepted: Nov 06, 2020; Published: Nov 21, 2020; Paper Id.: IJASROCT20203

\section{INTRODUCTION}

Agriculture is the main source of income generating entrepreneurship to the farmers in the world, due to the miss management in the crop production by using indiscriminate quantity of inorganic fertilizers and pesticides killed the natural biota in the soil. This is the main reason for deterioration of healthy soils towards poor soil fertility status. Evaluation of the soils for their quality to fix the suitable cropping system is the only solution left before us, therefore use of daily available raw materials in the farm should be reusedas a source of nutrient to the plantsbrings changes in the yield and population of soil biota, which can alsobring out the less cost of production 
by boosting the soil biota.This can maintains the soil sustainability for future generation.

As per several research outcomes says natural farming is the only way to bring out the rejuvenation instatus of soil health and fertility, so by creating the awareness in the young generation we have to restart this modern agriculture with the healthy eco-friendly agriculture to safeguard the future generation from the problems raised by the inorganic farming. In this context, before adopting natural farming we need to understand the soils in ground level, therefore this study needs soil survey to characterize the soils by analysing for nutrient content in soil which brings the lots of scope to fix the suitable cropping system to selected piece of land or region and identification of limitations of the soils in ground level. Therefore, this pilot study aims to provide site management by using soil resource inventory of soils of SRM College of Agricultural Sciences campus,Baburayanpettai village, Chengalpattu district, Tamil Nadu. The main objective is to focus on soil resource inventory, and evaluation of soil potentiality to adopt natural farming.

\section{MATERIAL AND METHODS}

\section{Study Area}

Baburayanpettai campus is located in Madhuranthagam taluk of Chengalpattudistrict. Initially the campus is having a total area of 181 acre land. The campus boundary is surrounded by Baburayanpettaiand Siruperpandi on the north, Kalathur villages on the south, Chithamoo on the east and Athivakkam village on the west.Based on the geological aspects the major rocks observed are Granites and Gneiss, limestone in the study area. Dykes, popularly known as black granite, occur in the study area as intrusive rock. The granite and gneiss show significant variations in their texture, colour, mineral assemblage and degree of weathering. Entire area consists of moderately sloping to nearly level in elevation. Based on the general slope, the area can be classified as almost flat.

\section{METHODOLOGY}

\section{Base Maps Used}

The detailed survey of the land resources occurring in the study area was carried out by using cadastral map as a base. The cadastral map shows field boundaries with their survey numbers, location of tanks, streams and other permanent features of the area. Apart from the cadastral map, remote sensing data products from IRS and Google earth at the scale of 1:8000 were used in conjunction with the cadastral map to identify the landforms and other surface features. The Imageries helped in the identification and delineation of boundaries between hills, uplands and lowlands, water bodies, forest and vegetated areas, roads, habitations and other cultural features of the area.

\section{Field Investigations}

Preliminary traverse of the entire campus was carried out with the help of cadastral map, Google earth imagery. During the traverseprofiles site were located at closely spaced intervals to take care of any change in the land features like break in slope, erosion, gravel, stones etc. In the selected sites, profiles (vertical cut showing the soil layers from the surface to the rock) were opened up to $200 \mathrm{~cm}$ or to the depth limited by rock or hard substratum and studied in detail for all their morphological and physical characteristics. The soil and site characteristics were recorded for all profile sites on a standard proforma as per the guidelines given in USDA Soil Survey Manual (Soil Survey Staff 1993). Apart from the profiles study surface soil samples are collected and analysed for major and micronutrients. 


\section{Site Characteristics}

Study area was categorized into different classes based on depth explained in Table No.1 represents the very deep depth soils category, it falls under the midslope physiographic unit and having the granite gneiss as parent material for origin of soils. Study area is facing the normal winter and hot summer. Study area is nearer to seashore experience the medium humidity therefore atmosphere is having high temperature mixed with moist air leads to rapid process of weathering of mineral matter. Since more heat radiation falls on the surface of soil leads to faster rate of mineralization of carbon to $\mathrm{Co}_{2}$, which is the main reason for less organic carbon in the soil. Therefore it's advised to use the live mulches to avoid faster rate of carbon mineralization.

Table 1: Site Characteristics of Pedon-1

\begin{tabular}{|l|l|}
\hline Location & Baburayanpettai campus \\
\hline Latitude & $11^{\circ} 54^{\prime} 35.4^{\prime \prime} \mathrm{N}$ \\
\hline Longitude & $76^{\circ} 46^{\prime} 23^{\prime \prime} \mathrm{E}$ \\
\hline Altitude (m) & 777 \\
\hline Landform and slope & $<1-3$ per cent slope with 50-150 m length, \\
\hline Physiographic unit & midland \\
\hline Geology & Granite gnese \\
\hline Plot no & 209 \\
\hline Parent material & Granite gnese \\
\hline Physiographic division & Southern Deccan plateau \\
\hline Erosion & slight \\
\hline Run off & slow \\
\hline Drainage & well \\
\hline Ground water depth (m) & $>50$ \\
\hline Flooding & No \\
\hline Vegetation & Neem, teak. \\
\hline Crops grown & --- \\
\hline Micro features & grassland \\
\hline Climate & very hot in Summer. \\
\hline
\end{tabular}

\section{Morphometric Characteristics of Deep Depth Soils of Study Area}

Soils are characterized by using USDA soil classification procedure, Table No-2 depicts the variation observed in the different layers from surface plough layer to parental rock, it was found that surface soils have dark greyish brown colour with clayey texture and having the angular blocky structure. Since it has having angular blocky structure leads to slickensides of soil aggregates therefore, it's not a good soil structure for very smooth rooting crops. As increase in the depth from surface to sub surface it was observed that the presence of $\mathrm{CaCo}_{3}$ concretions, since it occupies majorly in subsurface leading to soil calcareous. Increase in content of clay with increased depth and the development of soil structure, which indicated the development of cambic horizon (Gangopadhyay et al., 2001).

This is the major limitations observed in study area. Because of this limitation choice of crop is affected therefore remedial measures should be taken care to solve the problem, its recommended use effective incorporation Application of green manure and bulky organic manure to maintain the $\mathrm{pH}$ of the soil. Decomposition of green manure releases the organic acids, leads to $\mathrm{pH}$ level being brought down from higher to neutral status. 
Table 2: Morphometric Features of Pedon -1

\begin{tabular}{|l|l|l|}
\hline Horizon & Depth $\mathbf{( c m )}$ & \multicolumn{1}{c|}{ Profile Description } \\
\hline Ap & $0-30$ & $\begin{array}{l}\text { Dark greyish brown, 10YR4/2, clay, strong grade, very fine size, angular } \\
\text { blocky structure, very hard, very firm, very sticky, very plastic, fine many } \\
\text { roots, fine many pores, abrupt smooth boundary }\end{array}$ \\
\hline Bw1 $_{1}$ & $30-60$ & $\begin{array}{l}\text { Dark greyish brown, 10YR4/2, clay, strong grade, very fine size, angular } \\
\text { blocky structure, very hard, very firm, very sticky, very plastic, fine many } \\
\text { roots, fine many pores, abrupt smooth boundary }\end{array}$ \\
\hline Bw2 & $60-100$ & $\begin{array}{l}\text { Dark greyish brown, 10YR4/2, clay, strong grade, very fine size, angular } \\
\text { blocky structure, very hard, very firm, very sticky, very plastic, fine many } \\
\text { roots, fine many pores, abrupt smooth boundary }\end{array}$ \\
\hline BC & $100-200$ & $\begin{array}{l}\text { Dark reddish brown, 2.5YR3/4,fine gravel, sandy clay, moderate, medium to } \\
\text { coarse, subangular blocky, slightly hard, very friable, very sticky, slightly } \\
\text { plastic, clean wavy boundary, Presence of } \mathrm{CaCO}_{3}\end{array}$ \\
\hline $\mathbf{C}$ & Partially weathered parent material \\
\hline
\end{tabular}

\section{Physico-Chemical Properties of Soil}

The physico-chemical properties of study area are described in the Table 3. The soil $\mathrm{pH}$ ranged from 7.65 to 8.38 from surface to subsurface horizon. As the soil depth increases there is an increase of soil reaction were noticed,this may be due to the presence of $\mathrm{CaCo} 3$ concretions in the lower horizon. There is an evidence of illuviation of clay and formation of argillic horizon in the sub-surface layer and similar result was observed by Sitanggang et al. (2006).Soil salinity ranges from 0.20 to $0.8 \mathrm{dSm}^{-1}$ which results in non-salinity in nature for growing plants.Available nitrogen is observed lower in the surface and sub-surface horizons; this is because of higher rate of mineralization of carbon due to high temperature and less organic matter in the soil. Phosphorous shows lower status from surface to subsurface horizon because of fixed with caco3 as orthocalcium phosphate. Potassium is observed medium to high in status due to the presence of smectitic minerals abundantly present in the soil.Iron, Manganese and copper are showing more than their critical status this is due to not chelated with other chelating agent in the soil and due to the granite mineral matter naturally brings the more solubility of these metal ions.

Table 3: Physico- Chemical Properties of Study Area

\begin{tabular}{|c|c|c|c|c|c|c|c|c|c|c|}
\hline \multirow{2}{*}{$\begin{array}{c}\text { Depth } \\
\text { (cm) }\end{array}$} & \multirow{2}{*}{ Horizon } & pH) & Ec & $\mathbf{N}$ & $\mathbf{P}$ & $\mathbf{K}$ & $\mathbf{F e}$ & Mn & $\mathbf{Z n}$ & $\mathrm{Cu}$ \\
\hline & & $(1: 2.5$ & $\left(\mathrm{dsm}^{-1}\right)$ & \multicolumn{3}{|c|}{$\left(\right.$ Kgha $\left.^{-1}\right)$} & \multicolumn{4}{|c|}{$(\mathbf{p p m})$} \\
\hline Pedon-1 & \multicolumn{10}{|c|}{ Master Profile at Nearly Level Slope Land Transact } \\
\hline 0-30 & Ap & 7.65 & 0.20 & 56 & 15 & 100 & 8.01 & 5.81 & 0.27 & 2.77 \\
\hline 31-60 & $\mathrm{Bw}_{1}$ & 7.45 & 0.14 & 94.5 & 15 & 112.5 & 9.13 & 7.3 & 0.48 & 2.86 \\
\hline $60-100$ & $\mathrm{Bw}_{2}$ & 8.38 & 0.55 & 98 & 15 & 125 & 5.88 & 4.05 & 0.36 & 2.05 \\
\hline $100-200$ & $\mathrm{BC}$ & 8.34 & 0.98 & 35 & 14.5 & 187.5 & 4.91 & 2.19 & 0.93 & 1.95 \\
\hline$>200$ & $\mathrm{C}$ & \multicolumn{9}{|c|}{ Partially weathered parent material } \\
\hline
\end{tabular}

\section{CONCLUSIONS}

From the present study it can be concluded that soils of the study area was having different landforms with fundamental soil forming process. Due to this it was observed that soils are having some of the limitations like drainage, gravelliness, calcareousness and heavy clay content. Therefore to eradicate these limitations with eco-friendly it is advised to follow the natural farming with tree farming to boost the soil health for saving future days from this limitations. 


\section{ACKNOWLEDGEMENT}

I sincerely thank Dr.Thyagarajan, Dean (Agri.), FAS, SRM University for permitting me to use the facilities available at Baburayanapettai and his encouragement during the study.

\section{REFERENCES}

1. GANGOPADHYAY, S. K., BHATACHARYYA, T. AND SARKAR, T., 2001, Rubber growing soils of Tripura-their characteristics and classification. J. Indian Soc. Soil Sci., 49: 164-170.

2. SITANGGANG, MASRI, RAO, V.S. AHMED, NAYAN AND MAHAPATRA, S. K., 2006, Characterization and classification of soils in watershed area of Shikolpur, Guragon Dist. Haryana. J. Indian. Soc. Soil Sci., $\quad$ 54: 106-110.

3. SOIL SURVEY STAFF, 1951, Soil Survey Manual, U. S. Department of Agriculture Hand Book No.18, Washington. 

